\title{
Autocrine and Paracrine Roles for ATP and Serotonin in Mouse Taste Buds
}

\author{
Yijen A. Huang, ${ }^{1}$ Robin Dando, ${ }^{1}$ and Stephen D. Roper ${ }^{1,2}$ \\ ${ }^{1}$ Department of Physiology and Biophysics and 2 Program in Neuroscience, University of Miami School of Medicine, Miami, Florida 33136
}

Receptor (type II) taste bud cells secrete ATP during taste stimulation. In turn, ATP activates adjacent presynaptic (type III) cells to release serotonin (5-hydroxytryptamine, or 5-HT) and norepinephrine (NE). The roles of these neurotransmitters in taste buds have not been fully elucidated. Here we tested whether ATP or 5-HT exert feedback onto receptor (type II) cells during taste stimulation. Our previous studies showed NE does not appear to act on adjacent taste bud cells, or at least on receptor cells. Our data show that 5-HT released from presynaptic (type III) cells provides negative paracrine feedback onto receptor cells by activating 5 - $\mathrm{HT}_{1 \mathrm{~A}}$ receptors, inhibiting taste-evoked $\mathrm{Ca}^{2+}$ mobilization in receptor cells, and reducing ATP secretion. The findings also demonstrate that ATP exerts positive autocrine feedback onto receptor (type II) cells by activating P2Y1 receptors and enhancing ATP secretion. These results begin to sort out how purinergic and aminergic transmitters function within the taste bud to modulate gustatory signaling in these peripheral sensory organs.

\section{Introduction}

Taste buds are specialized sensory organs that transduce chemical stimuli into signals that are transmitted to the CNS via primary gustatory afferent fibers. Several neurotransmitters have been proposed for synapses in taste buds, including serotonin (5-HT), norepinephrine (NE), glutamate, acetylcholine, ATP, CCK, and neuropeptide Y (Nagahama and Kurihara, 1985; Nagai et al., 1998; Ogura, 2002; Lu et al., 2003; Kaya et al., 2004; Huang et al., 2005, 2007; Zhao et al., 2005; Finger et al., 2005; Romanov et al., 2007). However, only 5-HT, NE, and ATP have been unambiguously identified and shown to be released (Finger et al., 2005; Huang et al., 2005, 2007, 2008; Romanov et al., 2007). ATP is believed to excite gustatory primary afferent fibers and adjacent cells in the taste bud (Finger et al., 2005; Huang et al., 2007). Yet, purinoceptors are widely expressed in many taste cells (Kim et al., 2000; Baryshnikov et al., 2003; Bystrova et al., 2006; Hayato et al., 2007) and thus there may be additional targets for ATP within the taste bud. One goal of our paper is to characterize purinergic signaling in mouse taste buds and identify additional roles for ATP.

Similarly, the role of 5-HT in taste buds remains enigmatic. Injecting 5-HT into the lingual artery excited primary gustatory afferent fibers, implicating 5-HT at synapses between taste buds and sensory afferent axons (Esakov et al., 1983). Findings from simultaneous impalements of adjacent cells in amphibian taste

Received May 19, 2009; revised Sept. 22, 2009; accepted Sept. 24, 2009

This research was supported by National Institutes of Health-National Institute on Deafness and Other Communication Disorders Grant 5R01DC007630 (S.D.R.). Dr. Yutaka Maruyama kindly generated the ATP biosensor cells used in this study using constructs provided by Dr. A. Surprenant. 5-HT biosensor cells were a generous gift from Dr. K. Berg. Drs. N. Chaudhari and S. C. Kinnamon contributed valuable discussions to the work.

Correspondence should be addressed to Dr. Stephen D. Roper, Department of Physiology and Biophysics, University of Miami School of Medicine, 1600 Northwest 10th Avenue, Miami, FL 33136. E-mail: roper@miami.edu. DOI:10.1523/JNEUROSCI.2351-09.2009

Copyright $\odot 2009$ Society for Neuroscience $\quad 0270-6474 / 09 / 2913909-10 \$ 15.00 / 0$ buds suggested serotonergic paracrine signaling between taste cells (Ewald and Roper, 1994). Kaya et al. (2004) reported actions of 5-HT in rat taste buds and expression of 5-HT receptors that also led them to conclude serotonin is a paracrine neurotransmitter. Last, Heath et al. (2006) and O'Driscoll et al. (2008) showed that altering peripheral 5-HT in human subjects changed taste thresholds for sweet and bitter, presumably by acting on taste bud cells. Thus, a second goal of our report was to examine the detailed actions of 5-HT in mammalian taste buds.

There are multiple taste bud cell types involved in taste reception: types I, II, and III (Yee et al., 2001; Clapp et al., 2006; DeFazio et al., 2006). Type I taste cells express a glutamate transporter (Lawton et al., 2000) and an ecto-ATPase (Bartel et al., 2006), suggesting they are involved in clearing neurotransmitters. Type I cells also express amiloride-sensitive $\mathrm{Na}^{+}$ channels and inward-rectifying $\mathrm{K}^{+}$channels, implicating roles in $\mathrm{Na}^{+}$sensing and $\mathrm{K}^{+}$redistribution (Vandenbeuch et al., 2008a; Dvoryanchikov et al., 2009). Type II (receptor) cells express taste G-protein-coupled receptors (GPCRs) and transduce sweet, bitter, or umami taste stimuli, but they do not form conventional synapses. In response to taste stimulation, receptor cells secrete ATP. In contrast with receptor cells, type III (presynaptic) taste cells do not have GPCRs for taste stimuli but they do possess synaptic specializations and express synapse-related proteins (Yang et al., 2000; DeFazio et al., 2006). Presynaptic cells are excited by ATP secreted by receptor cells during taste stimulation. Presynaptic cells release 5-HT and NE when stimulated. In short, there are different transmitter systems and at least three categories of taste bud cells that are directly involved in taste signaling. Important synaptic interactions between these cells may be present.

In the present report, we use biosensor detection of neurotransmitter secretion to investigate cell-cell interactions between identified receptor and presynaptic taste cells, and specifically the 
roles of 5-HT and ATP in mediating negative and positive feedback on intercellular signaling.

An abstract of the findings was presented as a poster at the annual meeting of the Association for Chemoreception Sciences, April 2009 (Huang and Roper, 2009).

\section{Materials and Methods}

Animals. Adult mice of either sex were used in this study. We used wild-type and transgenic mice in the experiments, as indicated in Results, including P2Y4-null mice (Taconic \#TF0516, generated on a 129/SvEv-C57BL/6 background), P2Y1/P2Y2 double knock-out mice (Geary et al., 2005), transgenic mice expressing enhanced green fluorescent protein (GFP) under control of the PLC $\beta 2$ promoter (PLC $\beta 2-G F P$ ) (Kim et al., 2006), and transgenic mice expressing GFP under the GAD67 promoter (GAD-GFP) (Chattopadhyaya et al., 2004). In PLC $\beta 2-G F P$ mice, taste receptor (type II) cells express green fluorescent protein, thereby allowing us to identify this cell type with confidence during imaging experiments. Conversely, in GAD-GFP mice, the majority of presynaptic (type III) taste cells show green fluorescence (Tomchik et al., 2007). Mice were killed following National Institutes of Health guidelines, as approved by the University of Miami Animal Care and Use Committee.

Biosensor cells. Chinese hamster ovary $(\mathrm{CHO})$ cells expressing 5-HT2c receptors or $\mathrm{P} 2 \mathrm{X} 2 / \mathrm{P} 2 \mathrm{X} 3$ receptors (hereafter, "biosensor cells") were prepared and loaded with $5 \mu \mathrm{M}$ fura-2 AM as described in the study by Huang et al. (2007). An aliquot of fura-2-loaded, suspended biosensor cells was transferred to a recording chamber containing taste buds and/or taste cells and viewed with an Olympus IX 70 inverted microscope to test biosensor cell responses to bath-applied 5-HT (3 nM) or ATP (1 $\mu \mathrm{M})$. Responsive biosensor cells were drawn onto a fire-polished glass micropipette with gentle suction and used as a probe for testing transmitter release from taste cells and taste buds. In separate experiments we verified that biosensor cells were not affected by bath-applied $\mathrm{KCl}$, taste mix (cycloheximide, $10 \mu \mathrm{M}$; saccharin, $2 \mathrm{~mm}$; SC45647, $0.1 \mathrm{~mm}$; denatonium, $1 \mathrm{~mm}$ ) (Huang et al., 2005, 2007), or by the pharmacological compounds used in the present study, including BP554, 8-OH-DPAT, MRS2179, methysergide, paroxetine, and WAY100635 (supplemental Fig. S1, available at www.jneurosci.org as supplemental material). BP554, MRS2179, methysergide, and paroxetine were obtained from Tocris Bioscience. 8-OH-DPAT and WAY100635 were from Sigma.

Isolated taste buds and/or taste cells. We removed the lingual epithelium containing vallate taste buds from the posterior tongue by injecting 1 $\mathrm{mg} / \mathrm{ml}$ collagenase A (Roche), $2.5 \mathrm{mg} / \mathrm{ml}$ dispase II (Roche), and $1 \mathrm{mg} / \mathrm{ml}$ trypsin inhibitor (Sigma) directly under the epithelium surrounding the vallate papillae. The peeled epithelium was bathed in $\mathrm{Ca}^{2+}$-free solution for $30 \mathrm{~min}$ at room temperature and isolated taste cells were drawn into fire-polished glass micropipettes with gentle suction. Taste cells were transferred to a shallow recording chamber having a glass coverslip base and then loaded with $5 \mu \mathrm{M}$ fura-2 AM. The coverslip was coated with Cell-Tak (BD Biosciences) to hold taste cells firmly attached. Taste buds and/or taste cells were superfused with Tyrode's solution (in mM; 140 $\mathrm{NaCl}, 5 \mathrm{KCl}, 2 \mathrm{CaCl}_{2}, 1 \mathrm{MgCl}_{2}, 10 \mathrm{HEPES}, 10$ glucose, $10 \mathrm{Na}$-pyruvate, 5 $\mathrm{NaHCO}_{3}, \mathrm{pH} 7.4,310-320$ Osm). For nominally $\mathrm{Ca}^{2+}$-free Tyrode's solution, $\mathrm{MgCl}_{2}$ was substituted for $\mathrm{CaCl}_{2}$ (in mM; $140 \mathrm{NaCl}, 5 \mathrm{KCl}, 3$ $\mathrm{MgCl}_{2}, 10$ HEPES, 10 glucose, 10 Na-pyruvate, $5 \mathrm{NaHCO}_{3}$, 2 BAPTA, 2 EGTA, pH 7.4, 310-320 Osm).

$\mathrm{Ca}^{2+}$ imaging. For fura-2-loaded biosensor cells and isolated taste cells and taste buds, sequential images were recorded at $40 \times$ with a long-pass emission filter ( $\geq 510 \mathrm{~nm}$ ) when excited at $340 \mathrm{~nm}$ followed by $380 \mathrm{~nm}$ (Huang et al., 2007). Images were processed with Indec Workbench v5 software. Data shown are the F340/F380 ratios, indicating relative changes in $\left[\mathrm{Ca}^{2+}\right]_{\mathrm{i}}$.

Stimulation. Isolated taste buds and/or cells were stimulated by bath perfusion of $\mathrm{KCl}$ ( $50 \mathrm{~mm}$, substituted equimolar for $\mathrm{NaCl}$ ), taste mix (cycloheximide, $10 \mu \mathrm{M}$; saccharin, $2 \mathrm{~mm}$; SC45647, 0.1 mM; denatonium, $1 \mathrm{~mm}$ ), ATP, ADP, or UTP. All stimuli were made up in Tyrode's solution and applied at $\mathrm{pH} 7.2$ unless otherwise noted. Stimuli were applied for $30 \mathrm{~s}$ after which the perfusion was returned to Tyrode's solution. We

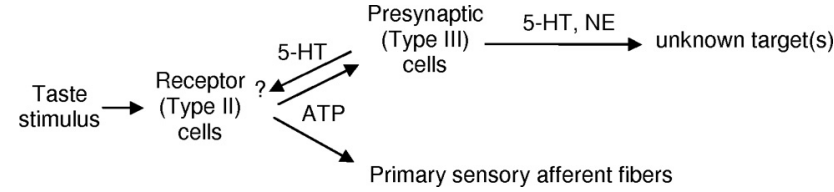

Figure 1. Schematic representation of hypothesized neurocrine and paracrine synaptic interactions involving ATP, 5-HT, and NE in taste buds. ATP secreted from receptor (type II) cells is believed to excite primary sensory afferent fibers as well as stimulate presynaptic (type III) cells (Finger et al., 2005; Huang et al., 2007). Presynaptic (type III) cells release 5-HT and NE (Huang et al., 2008). Targets for 5-HT may include receptor cells via paracrine secretion.

perfused the recording chamber with Tyrode's (i.e., wash) for a minimum of 3-5 min after a response had returned to baseline before testing another stimulus. We found this protocol produced the most repeatable and reliable responses for isolated cells and taste buds. All experiments were conducted at room temperature.

Quantification and data analysis. $\mathrm{Ca}^{2+}$ responses evoked by stimuli were measured as the difference between the peak value (F340/F380) and the baseline. We recorded the resting baseline for $30 \mathrm{~s}$ before each stimulus. Our criteria for accepting $\mathrm{Ca}^{2+}$ responses for analysis were that (1) responses could be elicited repetitively in the same cell by the same stimulus and (2) the peak response was at least twice the amplitude of baseline fluctuation. It should be noted that biosensor cell responses provide only a rough estimate of transmitter secretion from isolated taste cells and taste buds because the proximity of the biosensor to the release sites varies from cell to cell. Further, slight movement of the biosensor cell during drug application could introduce variation, though this variability would not be systematic. To mitigate against systematic changes upon drug application, responses were recorded before, during, and after applying drugs. Drug effects were reversible for all agents used in this study. Statistical analyses using paired Student's $t$ tests were applied to determine whether changes in responses following a given treatment were significant. Fisher's exact test was used to compare the incidence of responses between taste cells from knock-out mice and those from wildtype mice. Data presented in bar graphs show means \pm SEM.

\section{Results}

\section{Serotonin exerts negative paracrine feedback on receptor} (type II) cells

Important cell-to-cell interactions take place in taste buds immediately upon gustatory stimulation. Specifically, when excited by certain tastants (sweet, bitter, or umami compounds), receptor (type II) cells secrete ATP. ATP stimulates adjacent presynaptic (type III) cells to release 5-HT and NE (Huang et al., 2005, 2008). NE does not appear to act on adjacent taste bud cells, or at least on receptor cells (Huang et al., 2008). However, we and others have suggested that 5-HT mediates paracrine interactions between taste cells (Ewald and Roper, 1994; Kaya et al., 2004). Thus, we tested whether 5-HT might specifically exert feedback onto receptor cells as outlined in Figure 1.

To test this hypothesis, we first isolated taste receptor cells $(n=22)$ and taste buds $(n=12)$ and measured taste-evoked ATP secretion in the absence and presence of bath-applied 5-HT or the 5-HT receptor agonists 8-OH-DPAT and BP554. Applying 5-HT did not directly evoke $\mathrm{Ca}^{2+}$ responses in either receptor or presynaptic cells (supplemental Fig. S2, available at www. jneurosci.org as supplemental material). However, in the presence of serotonin $(10 \mathrm{nM})$, taste-evoked $\mathrm{Ca}^{2+}$ mobilization in receptor cells was markedly inhibited and ATP secretion was abolished (Fig. 2A). We applied 5-HT at $10 \mathrm{~nm}$ because tasteevoked release of serotonin appears to generate a local concentration on this order of magnitude (e.g., compare 5-HT biosensor calibration responses with taste-evoked responses in isolated taste buds in the work of Huang et al., 2005, their Fig. 2). 
A
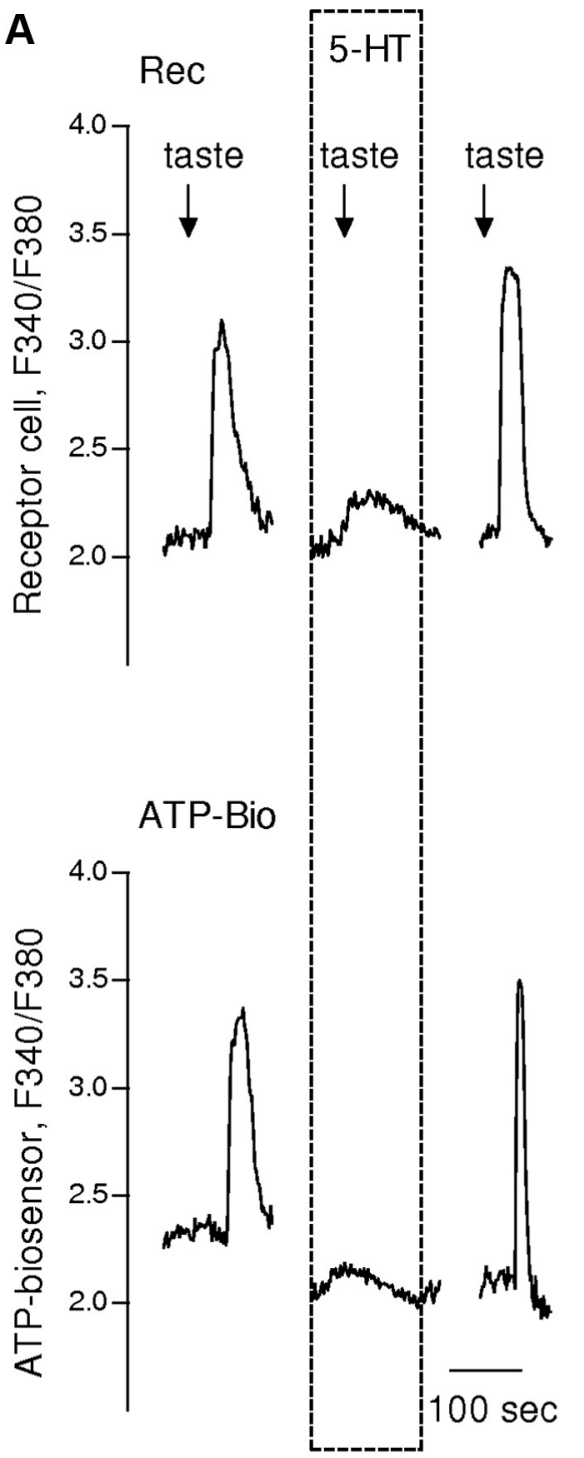

B
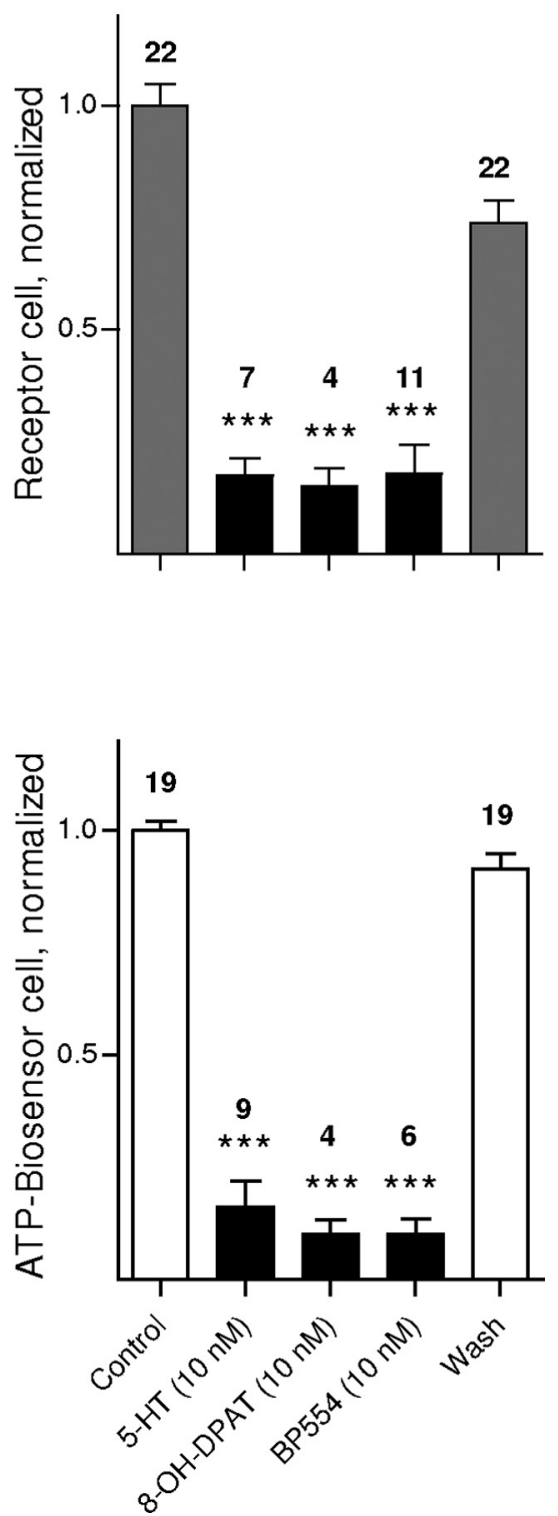

Figure 2. Isolated receptor (type II) cells are inhibited by 5-HT and agonists of 5-HT ${ }_{1 \mathrm{~A}}$ receptors. $\boldsymbol{A}$, An isolated receptor cell (Rec) was apposed to an ATP biosensor cell (ATP-Bio) to monitor transmitter secretion evoked by taste stimulation (arrows; see Materials and Methods for composition of taste mixture used here and in subsequent figures). Responses in the receptor cell and biosensor were recorded concurrently (top, bottom traces in $A$, respectively). The presence of $5-\mathrm{HT}$ ( $10 \mathrm{nM}$, perfused during interval shown by dashed box) profoundly inhibited taste-evoked responses in the receptor cell (top trace) and its ability to secrete ATP (bottom trace). The inhibitory effects of 5-HT were reversible; taste-evoked responses returned as soon as 5 -HT was removed, as shown. Ordinate here and in all subsequent figures, unless otherwise specified, shows the fura-2 imaging ratio ( $F 340 / F 380$; see Materials and Methods). $B$, Summary of data from experiments such as shown in $A$, including $5-\mathrm{HT}_{1 \mathrm{~A}}$ receptor agonists. Bars show means $\pm \mathrm{SEM}$ for taste-evoked responses from receptor cells (top, shaded bars) and concurrent measurement of ATP secretion (bottom, open bars) before, during (black bars), and after applying $10 \mathrm{~nm} 5-\mathrm{HT}, 8-0 \mathrm{H}-\mathrm{DPAT}$, or BP554. Numbers above bars indicate the number of data points averaged. In some cases, it was not possible to complete the recording from pairs of receptor/biosensor cells, in which case the data were excluded, explaining the mismatch in numbers. Data were normalized to the average response recorded before drug application (i.e., control). ${ }^{* * *} p<0.001$; Student's paired $t$ test.

Kaya et al. (2004) reported that taste cells express 5- $\mathrm{HT}_{1 \mathrm{~A}}$ receptors. Thus, we tested the effects of selective $5-\mathrm{HT}_{1 \mathrm{~A}}$ receptor agonists, 8-OH-DPAT and BP554, on isolated receptor cells. A low concentration $(10 \mathrm{nM})$ of 8-OH-DPAT inhibited tasteevoked $\mathrm{Ca}^{2+}$ mobilization in receptor cells and reduced their ATP secretion in all 4 cells tested, as did BP554 (10 nM) in 10 of 11 cells tested (Fig. $2 B$ ).
Gustatory stimuli evoke 5-HT release from presynaptic cells downstream of receptor cell excitation, as outlined in Figure 1 . Thus, we attempted to manipulate endogenous 5-HT levels by blocking reuptake of this monoamine during taste stimulation. Paroxetine, a serotonin reuptake inhibitor, would be expected to elevate intercellular 5-HT released during taste stimulation. Indeed, taste-evoked ATP secretion from isolated taste buds was significantly decreased in the presence of paroxetine (100 nM) (Fig. 3C,D), consistent with the inhibitory actions of 5-HT documented above and in Figure 3, $A$ and $B$. [Importantly, as noted in Materials and Methods, neither paroxetine nor any other pharmacological agent used in this report affected the sensitivity of our biosensor cells, themselves (supplemental Fig. S1, available at www.jneurosci.org as supplemental material)].

The converse of this experiment, namely blocking the action of endogenous 5-HT in isolated taste buds, was also investigated. We bath-applied methysergide (10 nM), a broadly acting 5-HT1 and 2 receptor antagonist (Fig. $3 E, F$ ), or WAY100635 $(10 \mathrm{nM})$, a selective $5-\mathrm{HT}_{1 \mathrm{~A}}$ receptor antagonist (Fig. 3G,H) and tested the ability of taste stimulation to excite receptor cells and to evoke ATP secretion. With either of these antagonists, taste-evoked ATP release was elevated nearly twofold (Fig. $3 E-H$ ). We also bathapplied $m$-CPBG ( $m$-chlorophenylbiguanide hydrochloride (50 nm, Tocris Bioscience), a potent and selective 5-HT3 receptor agonist (Kilpatrick et al., 1990; Morán et al., 2008) to test its effects on ATP secretion. Taste-evoked ATP secretion was not affected by $m$-CPBG (data not shown).

Last, we tested whether 5-HT (10 nM) affected presynaptic taste cells. Bathapplied 5-HT did not alter depolarization $(\mathrm{KCl})$-evoked $\mathrm{Ca}^{2+}$ transients in presynaptic cells (supplemental Fig. S2, available at www.jneurosci.org as supplemental material), suggesting that the inhibitory actions of this biogenic amine, at least at physiologically relevant concentrations, are limited to receptor cells.

Collectively, the above experiments indicate that during taste stimulation, 5-HT exerts negative feedback onto receptor (type II) cells. Moreover, this inhibitory feedback is mediated by $5 \mathrm{HT}_{1 \mathrm{~A}}$ receptors.

\section{ATP stimulates receptor and presynaptic cells via P2Y purinoceptors}

We isolated individual receptor or presynaptic taste cells and bath-applied ATP $(1-10 \mu \mathrm{M})$. As shown previously, presynaptic cells showed robust $\mathrm{Ca}^{2+}$ signals in response to ATP stimulation 
A

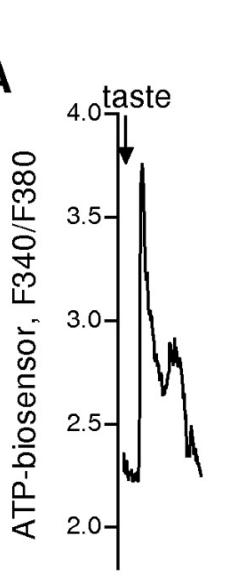

C

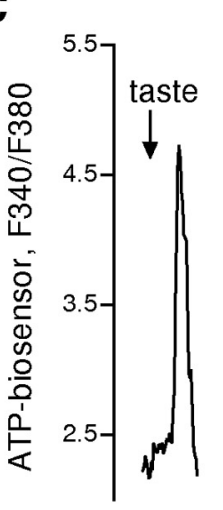

E

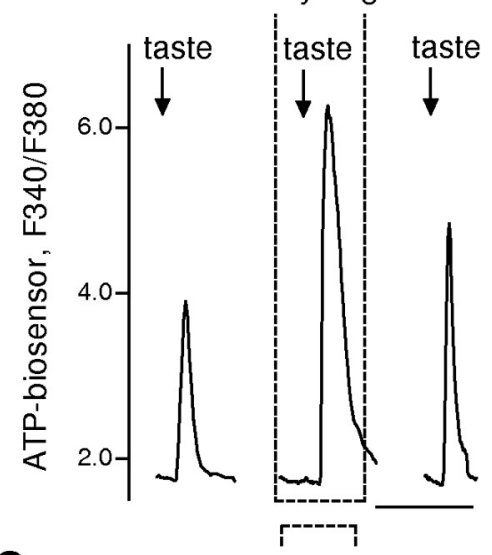

G

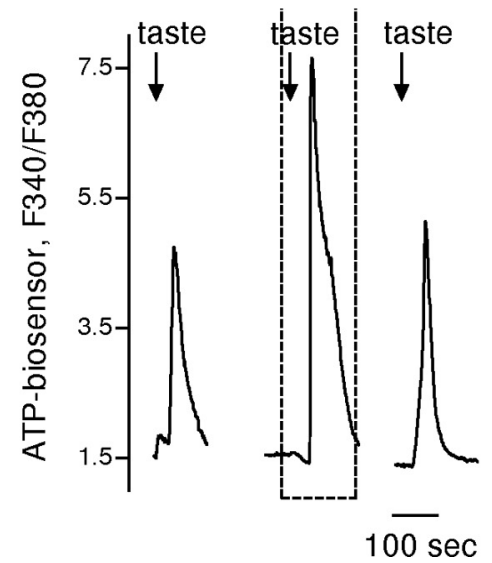

taste taste $\quad$ B

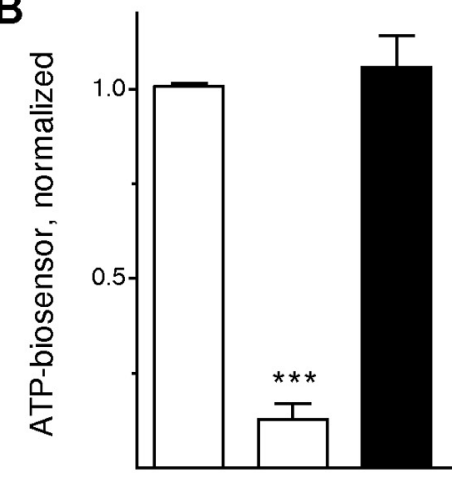

D

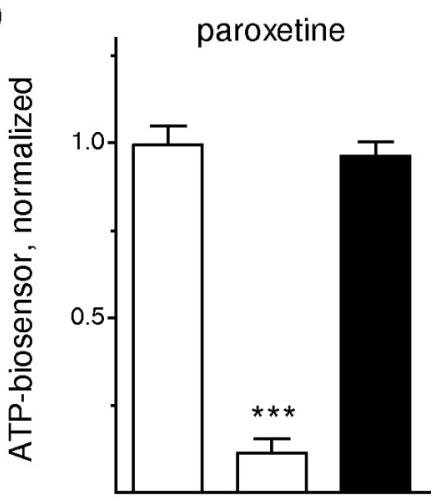

$\mathbf{F}$

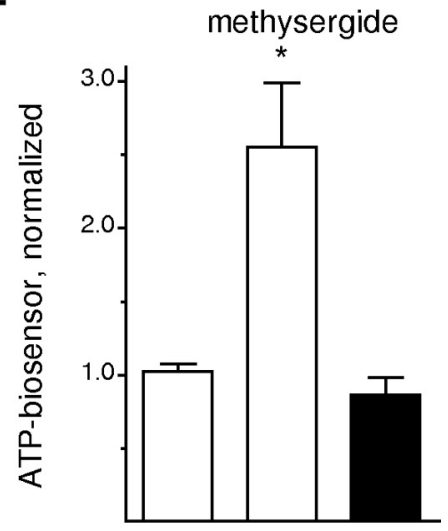

H

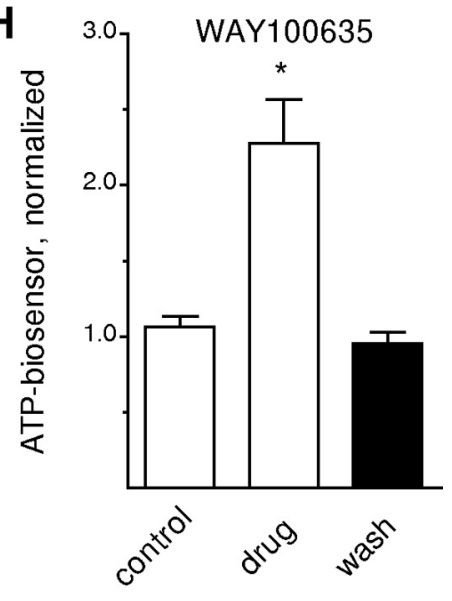

(Huang et al., 2007), confirming the feedforward purinergic signal. Interestingly, receptor cells were also excited by ATP, suggesting the possibility of positive feedback (see below).

To distinguish ionotropic $\mathrm{P} 2 \mathrm{X}$ receptors from metabotropic P2Y purinoceptors on receptor and presynaptic cells, we substituted $\mathrm{Ca}^{2+}$ with $\mathrm{Mg}^{2+}$ in the bath. Removing extracellular $\mathrm{Ca}^{2+}$ did not diminish ATP-evoked $\mathrm{Ca}^{2+}$ signals in either receptor or presynaptic cells (Fig. 4). This indicates that presynaptic and receptor cells both express P2Y receptors. These experiments do not rule out a contribution from $\mathrm{P} 2 \mathrm{X}$ receptors for ATP $\leq 10 \mu \mathrm{M}$, but if ATP also stimulates $\mathrm{Ca}^{2+}$ influx via $\mathrm{P} 2 \mathrm{X}$ receptors, the influx would comprise a small component of the $\mathrm{Ca}^{2+}$ signal.

We next attempted to identify the specific subtypes of P2Y purinoceptors on receptor and presynaptic cells. Calcium imaging of taste cells is not an ideal preparation for collecting detailed profiling of receptor pharmacology. Nonetheless, we were able to obtain a rough characterization of the purinoceptors involved. As an initial screen, we tested the relative potencies of ATP, ADP, and UTP on receptor and presynaptic cells. ATP and ADP, but not UTP (all at $1 \mu \mathrm{M}$ ) evoked robust re-

$\leftarrow$

Figure 3. Manipulating extracellular serotonin or blocking $5-\mathrm{HT}_{1 \mathrm{~A}}$ receptors in taste buds modulates ATP neurosecretion. Whole taste buds were isolated from mouse vallate papillae to retain cell-to-cell communication between receptor and presynaptic cells (Huang et al., 2007). Traces show taste-evoked secretion of ATP from the receptor cells in a taste bud, measured with an ATP biosensor positioned against the taste bud. $A$, Responses of an ATP biosensor cell positioned next to a taste bud. Similar to the results shown in Figure $2 A$ for isolated single receptor cells, the presence of bath-applied 5-HT (10 nM, perfused throughout the interval shown by dashed box) reversibly reduced taste-evoked ATP secretion from the receptor cells within the taste bud. Arrows, Taste stimulation. B, Summary of data from eight experiments. Bars show means \pm SEM for ATP biosensor signals in response to taste stimulation (as in $\boldsymbol{A}$ ), normalized to the average taste-evoked response in absence of drug (i.e., control). C, Paroxetine, which blocks 5-HT reuptake and thus would be expected to lead to an accumulation of extracellular 5-HT released during taste stimulation, mimics the actions of bath-applied 5-HT. As shown here, perfusion with paroxetine ( $100 \mathrm{~nm}$, dashed box) reduced tasteevoked ATP secretion. $\boldsymbol{D}$, Summary of data from five experiments, plotted as in $\boldsymbol{B}$. $\boldsymbol{E}$, Methysergide, a $5-\mathrm{HT}_{1}$ and $5-\mathrm{HT}_{2}$ receptor antagonist, greatly enhances ATP secretion from taste buds. Here, bath-applied methysergide (10 nм) nearly doubled taste-evoked ATP secretion from the taste bud. $\boldsymbol{F}$, Summary of data from five experiments, plotted as in $\boldsymbol{B}$. $\boldsymbol{G}$, WAY100635, a $5-\mathrm{HT}_{1 \mathrm{~A}}$ selective antagonist, also enhances taste-evoked ATP secretion. Here, WAY100635 (10 nm) produced a large increase in ATP secretion. $\boldsymbol{H}$, Summary of data from five experiments, plotted as in $\boldsymbol{B} .{ }^{*} p<0.05 ;{ }^{* * *} p<$ 0.001 ; Student's paired $t$ test. 


\section{A $\operatorname{Rec}$}
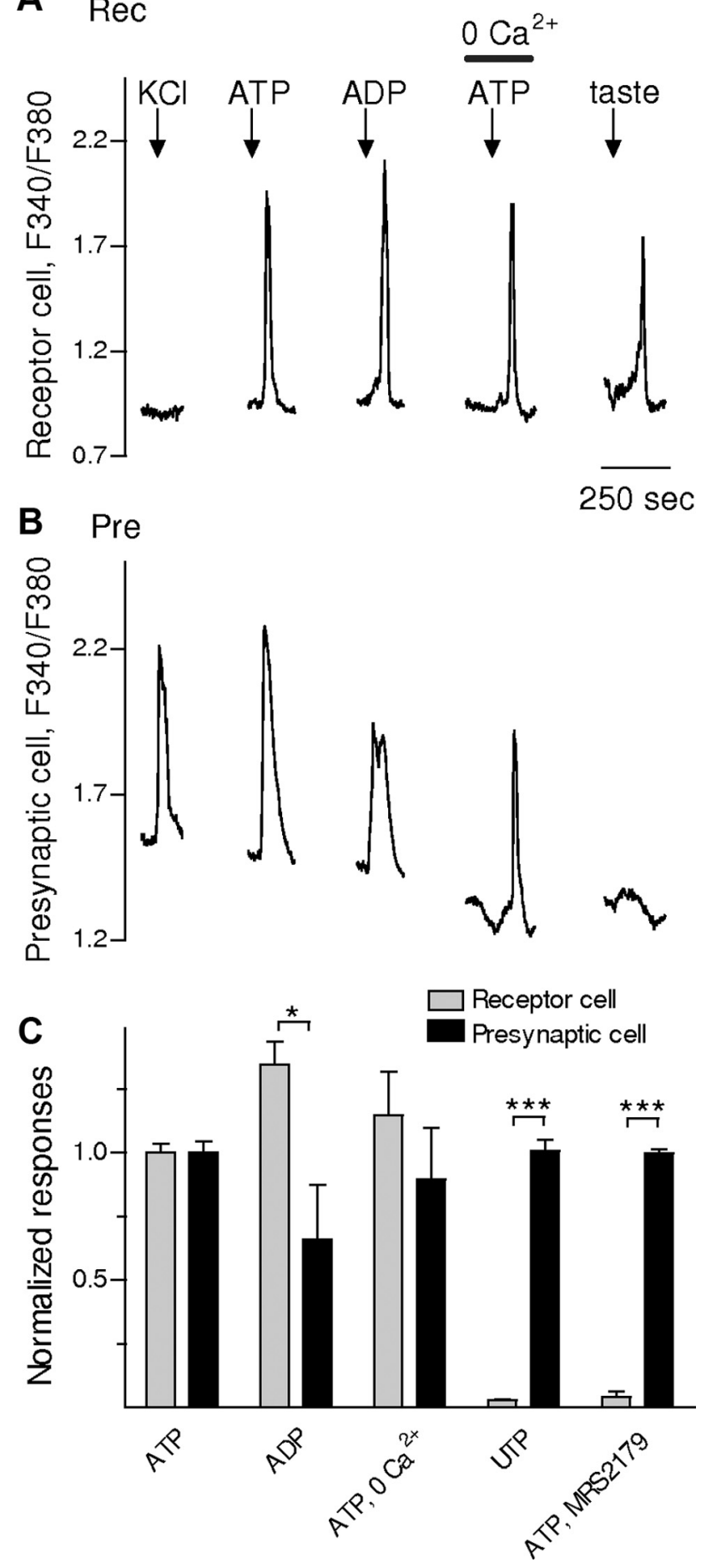

Figure 4. ATP stimulates P2Y receptors on receptor and presynaptic taste cells. Stimulating isolated taste cells with bath-applied ATP, ADP, or UTP elicits $\mathrm{Ca}^{2+}$ mobilization in receptor (type II) cells and presynaptic (type III) cells. A, A receptor cell (Rec) did not respond to $\mathrm{KCI}$ (50 $\mathrm{mm}$ ) depolarization but did to taste stimulation (DeFazio et al., 2006) (first and last stimuli, respectively, shown by arrows above the traces). Taste stimulation was the same as for Figure 2 . This cell also showed robust $\mathrm{Ca}^{2+}$ signals in response to ATP $(1 \mu \mathrm{M})$ and ADP $(1 \mu \mathrm{M})$. ATPevoked $\mathrm{Ca}^{2+}$ mobilization was not affected when $\mathrm{Ca}^{2+}$ was eliminated from the bathing solution (0 $\mathrm{Ca}^{2+} /$ ATP). These findings indicate that ATP-evoked responses in receptor cells were generated by release of intracellular $\mathrm{Ca}^{2+}$, consistent with excitation of $\mathrm{P} 2 \mathrm{Y}$ receptors. $B, \mathrm{Ca}^{2+}$ mobilization in an isolated presynaptic cell (Pre), identified by its response to $\mathrm{KCl}$ but not taste (stimuli are the same as marked above traces in $\boldsymbol{A}$ ). The results also indicate that $\mathrm{Ca}^{2+}$ responses in this cell are due to intracellular $\mathrm{Ca}^{2+}$ release (excitation of $\mathrm{P} 2 \mathrm{Y}$ receptors). C, Responses to ATP, ADP, and UTP (all at $1 \mu \mathrm{M}$ ) are compared for receptor and presynaptic cells.

\section{A $\operatorname{Rec}$}

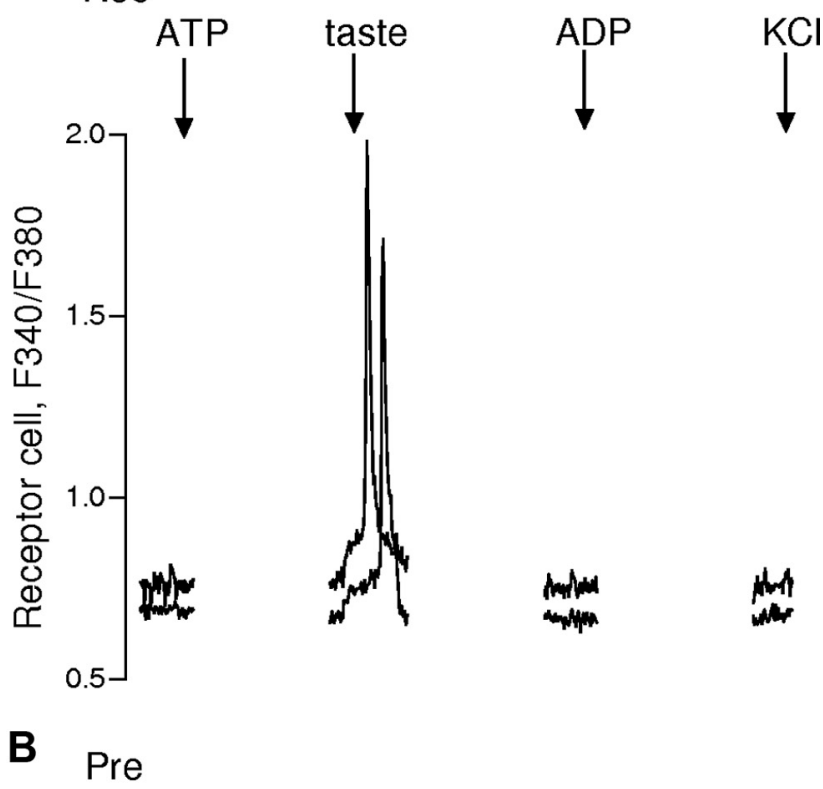

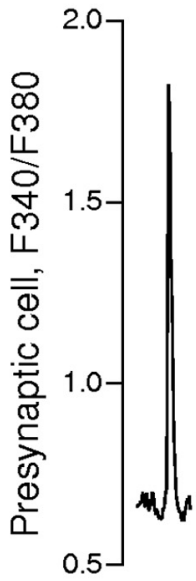

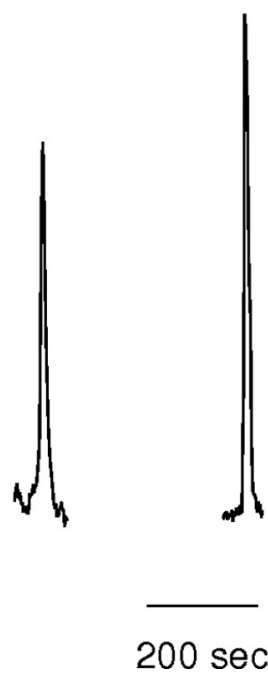

Figure 5. Receptor (type II) cells in mice lacking P2Y1 and P2Y2 receptors do not respond to ATP or ADP. Receptor and presynaptic cells isolated from vallate papillae of P2Y1/P2Y2 double K0 mice were identified by their responses to $\mathrm{KCl}(50 \mathrm{~mm})$ and taste stimulation (taste mixture, as in Fig. 2). $\boldsymbol{A}$, Superimposed responses from two receptor cells (Rec) showed normal taste-evoked responses but absence of responses to ATP or ADP (both at $1 \mu \mathrm{m}$ ) (stimuli marked by arrows above traces). $\boldsymbol{B}$, Presynaptic cell (Pre) in the same experiment responded to ATP $(1 \mu \mathrm{M}), \operatorname{ADP}(1 \mu \mathrm{M})$, and KCI (50 mM), consistent with activation of purinoreceptors other than $\mathrm{P} 2 \mathrm{Y} 1$ (or $\mathrm{P} 2 \mathrm{Y} 2$ ).

sponses in receptor cells (Fig. 4). These results are consistent with the expression of $\mathrm{P} 2 \mathrm{Y} 1$ receptors on receptor cells. Accordingly, MRS2179 (10 $\mu \mathrm{M})$, a selective antagonist of P2Y1 receptors (Mutafova-Yambolieva et al., 2007), abolished ATP-evoked

Bars show means \pm SEM. Data were normalized to the average ATP-evoked responses for each cell type. Receptor cells show robust $\mathrm{Ca}^{2+}$ mobilization in response to ATP and ADP, but not UTP. The response profile for receptor cells (shaded bars) $(n=23)$ suggests activation of P2Y1 receptors (ADP $>$ ATP $\gg$ UTP). In contrast, presynaptic cells (filled bars) $(n=14)$ appear to express P2Y4 receptors (ATP UTP $>$ ADP). Bath-applied MRS2179 $(10 \mu \mathrm{M})$, a selective P2Y1 receptor antagonist, significantly reduced ATP responses in receptor cells but not in presynaptic cells, further supporting the presence of P2Y1 receptors on receptor cells. ${ }^{*} p<0.05 ;{ }^{* * *} p<$ 0.001 ; Student's paired $t$ test. 
A

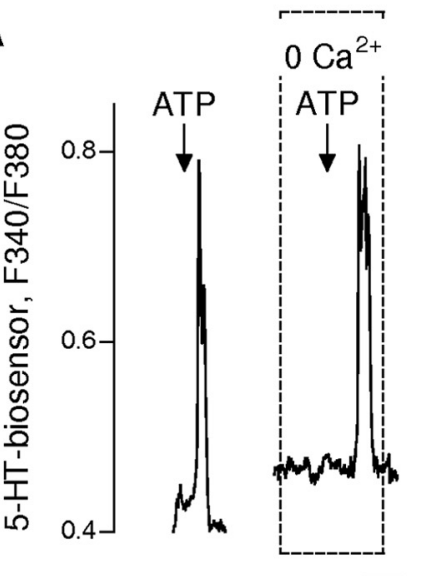

C

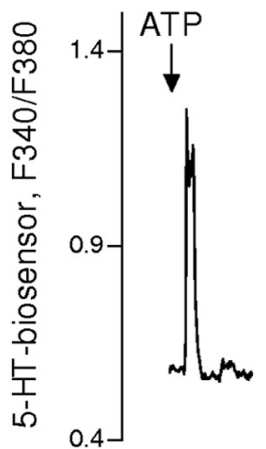

D

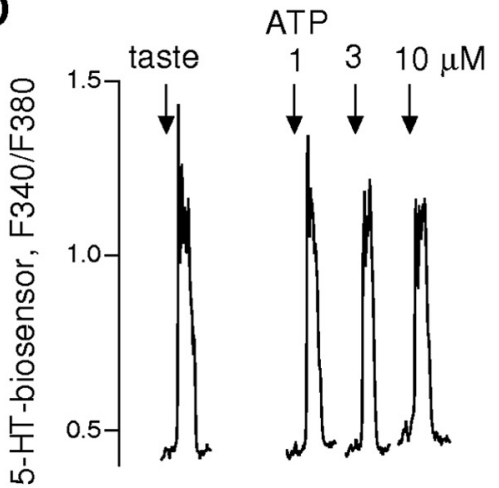

E

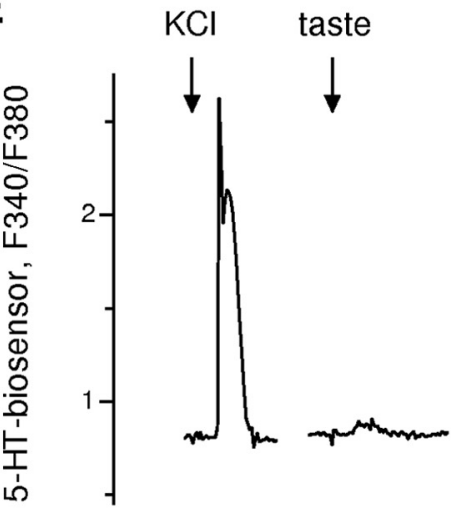

MRS2179

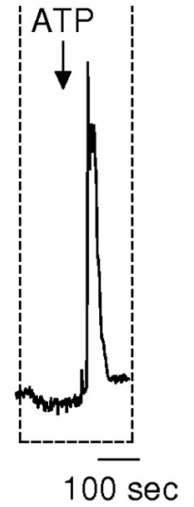

B

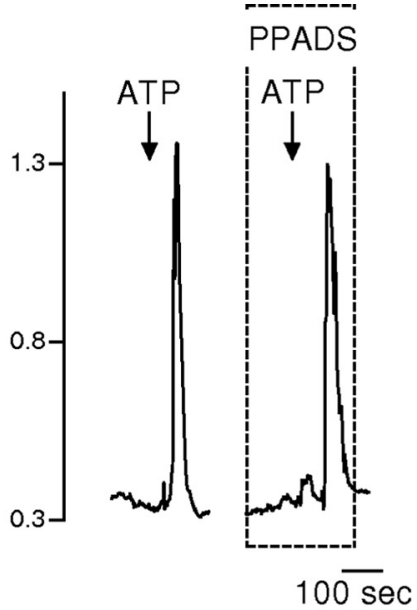

ADP
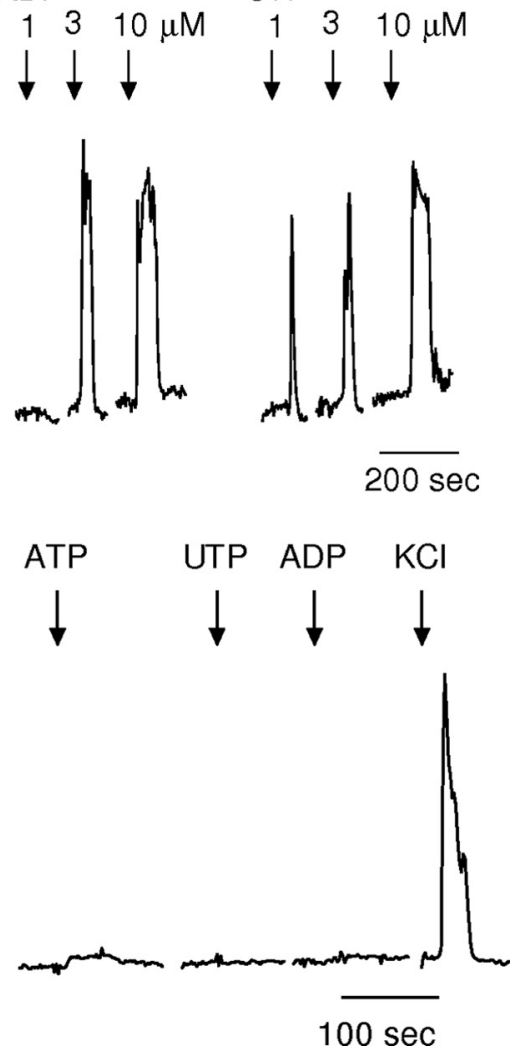

$\mathrm{Ca}^{2+}$ signals in receptor cells. In contrast, presynaptic cells responded to $1 \mu \mathrm{M}$ ATP, ADP, and UTP, a finding inconsistent with P2Y1 receptors. Furthermore, ATP responses in presynaptic cells were not affected by the P2Y1 antagonist, MRS2179 (Fig. 4).

To test these receptor characterizations further, we isolated individual receptor cells from mutant mice lacking P2Y1 and P2Y2 receptors (Fig. 5). Specifically, we isolated 14 receptor cells from P2Y1/P2Y2 double knock-out mice. None of these receptor cells responded to $1 \mu \mathrm{M}$ ADP and 12 of 14 failed to respond to 1 $\mu \mathrm{M}$ ATP. In contrast, all receptor cells of wild-type mice showed robust $\mathrm{Ca}^{2+}$ responses to ATP (21 of 21) and ADP (14 of 14). These differences between the double knock-out mice and wild-type mice were statistically significant $(p<0.001$; paired Fisher's exact test). In contrast, ATP- and ADP-evoked responses in presynaptic cells did not show any difference between wild-type $(n=30)$ and mutant $(n=10)$ mice (Fig. 5).

In summary, the above findings suggest that receptor cells express $\mathrm{P} 2 \mathrm{Y} 1$ receptors and presynaptic cells predominantly express $\mathrm{P} 2 \mathrm{Y}$ receptors other than $\mathrm{P} 2 \mathrm{Y} 1$.

To extend the investigation of $\mathrm{P} 2 \mathrm{Y}$ receptors expressed on presynaptic cells, we recorded 5-HT secretion from taste buds

$\leftarrow$

Figure 6. ATP stimulates 5-HT release by activating P2Y receptors. We measured serotonin release from the presynaptic cells in isolated taste buds, using 5-HT biosensors, as described in the work of Huang et al. $(2005,2007) . A, \mathrm{Ca}^{2+}$ responses from 5 -HT biosensor cells positioned against isolated taste buds. Bath-applied ATP (1 $\mu \mathrm{M}$, arrows) stimulated 5-HT release. 5-HT release was unaffected by removing $\mathrm{Ca}^{2+}$ from the bath. $\boldsymbol{B}$, Similarly, ATP-evoked release of $5-\mathrm{HT}$ was unaffected by PPADS $(10 \mu \mathrm{M})$, a nonselective antagonist of $P 2 X, P 2 Y 1$, and P2Y2 receptors. This recording is from a different experiment than shown in $\boldsymbol{A} . \boldsymbol{C}$, In another experiment, ATP-evoked 5-HT release was unaffected by MRS2179 (10 $\mu \mathrm{M})$, a selective P2Y1 antagonist. Data in $\boldsymbol{A}-\mathbf{C}$ implicate ATP receptors other than $P 2 X, P 2 Y 1$, and $P 2 Y 2$ purinoreceptors underlying ATP-evoked release of serotonin from presynaptic cells. $\boldsymbol{D}$, Consecutive 5-HT biosensor activation is shown in response to stimulating an isolated taste bud first with a taste mixture (10 $\mu \mathrm{m}$ cycloheximide and $2 \mathrm{~mm}$ saccharin), followed by ATP, ADP, and UTP (all at 1, 3, and $10 \mu \mathrm{M}$ ). All stimuli except for the lowest concentration of ADP evoked 5-HT release from the presynaptic cells in the taste bud. This response profile (ATP UTP $>$ ADP) is consistent with P2Y4 receptors on presynaptic taste cells being responsible for stimulating 5 -HT release. $\boldsymbol{E}$, Taste buds were isolated from vallate papillae of P2Y4 knock-out mice. This record shows an example of 5-HT biosensor responses evoked by stimulating a taste bud with $\mathrm{KCl}(50 \mathrm{~mm})$, taste mix, ATP, UTP, and ADP (all at $1 \mu \mathrm{M})$. Only $\mathrm{KCl}(50 \mathrm{~mm})$ depolarization stimulated 5 - $\mathrm{HT}$ release, further supporting the role of P2Y4 purinoreceptors on presynaptic cells as the trigger for serotonin secretion. 
in response to purinergic stimulation. Serotonin secretion elicited by ATP stimulation is independent of extracellular $\mathrm{Ca}^{2+}$ (Fig. 6A). This is consistent with our findings above that presynaptic cells express P2Y (i.e., metabotropic) receptors. ATPevoked 5-HT secretion in taste buds was not affected by pyridoxal-phosphate-6-azophenyl-2', $4^{\prime}$-disulfonate (PPADS) (Fig. $6 \mathrm{~B}$ ), an antagonist of $\mathrm{P} 2 \mathrm{X}, \mathrm{P} 2 \mathrm{Y} 1$, and $\mathrm{P} 2 \mathrm{Y} 2$ receptors, or by MRS2179 (Fig. 6C). We also tested the ability of ATP, UTP, or ADP to elicit 5-HT secretion from taste buds. A low concentration $(1 \mu \mathrm{M})$ of ATP and UTP, but not of ADP evoked 5-HT secretion from taste buds (Fig. 6D). These findings implicated that presynaptic cells express $\mathrm{P} 2 \mathrm{Y} 4$ receptors.

To validate the identification of $\mathrm{P} 2 \mathrm{Y} 4$ receptors on presynaptic cells, we isolated taste buds from P2Y4 knock-out mice and tested for the presence of taste-evoked 5-HT secretion. We rarely detected 5-HT secretion when taste buds were stimulated by taste compounds, ATP, UTP, or ADP (Fig. 6E). From a total of 41 isolated taste buds, we were able to identify taste-evoked 5-HT release (i.e., 5-HT biosensor responses) in only one case. This is significantly different from the incidence of taste-evoked 5-HT in taste buds isolated from wild-type mice ( 80 of 384 taste buds; $p<$ 0.01 ). We conclude that presynaptic cells express P2Y4 receptors.

ATP provides positive autocrine feedback onto receptor cells Because receptor cells secrete ATP upon taste stimulation and because these cells also express P2Y1 receptors, we tested whether there was purinergic autocrine positive feedback during taste activation. Specifically, we measured taste-evoked ATP secretion from isolated taste buds (wild-type mice) in the presence of a P2Y1 antagonist. ATP secretion was significantly decreased $(n=$ $4 ; p<0.01)$ when MRS2179 $(10 \mu \mathrm{M})$ was added to the bath (Fig. $7 A$ ), showing that ATP likely has an autocrine feedback on receptor cells. (As an important note, we confirmed that this concentration of MRS2179 did not affect ATP biosensor cells, consistent with ATP biosensor cells stably expressing P2X1/ $\mathrm{P} 2 \mathrm{X} 2$ receptors).

We extended the analysis of purinergic feedback in taste buds. We investigated whether autocrine feedback influenced the ability of receptor cells to stimulate 5-HT release from presynaptic cells. Taste-evoked 5-HT release from isolated taste buds was significantly decreased in the presence of the P2Y1 blocker MRS2179 $(n=6 ; p<0.01)$ (Fig. 7B), consistent with the above finding that MRS2179 also reduced ATP secretion. As controls for nonspecific depression of taste bud function, we tested the ability of $\mathrm{KCl}$ depolarization to evoke 5 - $\mathrm{HT}$ release under the same conditions. Depolarization-evoked 5-HT secretion from isolated taste buds was not affected by MRS2179. MRS2179 also had no direct effect on taste-evoked responses in receptor cells. (supplemental Fig. S3, available at www.jneurosci.org as supplemental material).

\section{Discussion}

The present report indicates that ATP and 5-HT provide feedback signals within vallate taste buds during taste transmission and identifies the taste cells that express specific receptor subtypes for these transmitters. ATP and its degradation product ADP provide positive autocrine feedback onto taste receptor (type II) cells via P2Y1 receptors. In contrast, 5-HT from presynaptic (type III) cells exerts negative feedback onto receptor cells via $5-\mathrm{HT}_{1 \mathrm{~A}}$ receptors. This scenario is summarized in Figure 8. Whether these mechanisms apply to taste buds in other taste fields (fungiform, palate, foliate) remain to be tested.
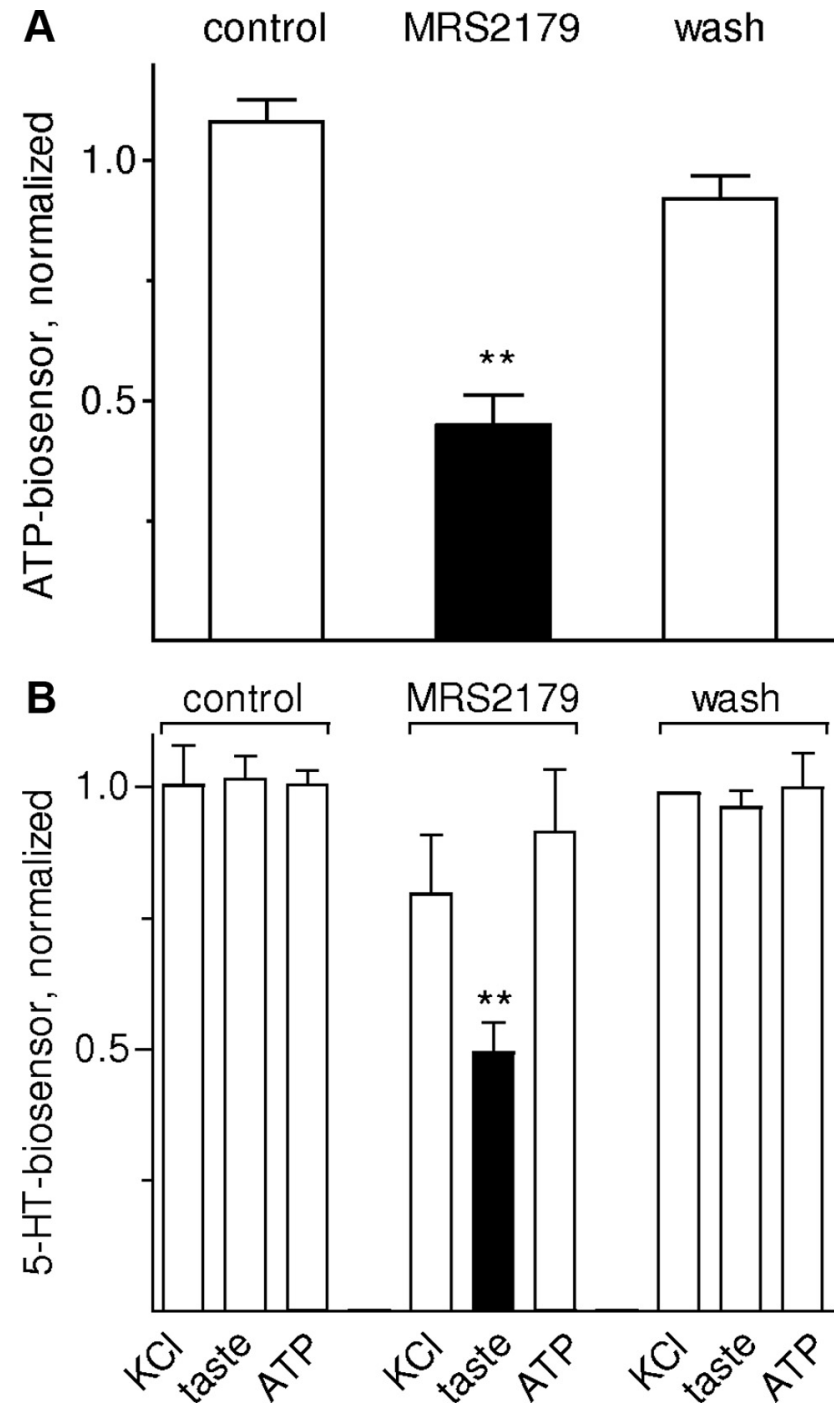

Figure 7. ATP exerts positive autocrine feedback on its secretion from taste buds. We used ATP- and 5-HT-biosensors to measure release of ATP $(\boldsymbol{A})$ or 5-HT $(\boldsymbol{B})$ from isolated taste buds. $\boldsymbol{A}$, Taste-evoked ATP secretion measured before, during (black bar), and after MRS2179, a selective P2Y1 inhibitor. Taste-evoked ATP secretion was significantly reduced by $10 \mu \mathrm{m}$ $\operatorname{MRS} 2179(n=4)$. Biosensor sensitivity was unaffected. Bars show means \pm SEM here and in $\boldsymbol{B}$. Data were normalized to average ATP-evoked responses before drug treatment. $\boldsymbol{B}, 5$ - $\mathrm{HT}$ biosensor responses recorded when depolarizing taste buds $(50 \mathrm{mM} \mathrm{KCl}$ ) or stimulating with taste mix or ATP (1 $\mu \mathrm{M})$. Blocking P2Y1 receptors with MRS2179 significantly reduced taste-evoked 5 -HT release (black bar) $(n=6)$. Data were normalized to average ATP-evoked responses before drug treatment. Findings shown in $\boldsymbol{A}$ and $\boldsymbol{B}$ are consistent with the hypothesis that $\mathrm{P} 2 \mathrm{Y} 1$ receptors on receptor cells mediate positive (autocrine) feedback and enhance ATP secretion during gustatory stimulation of taste buds. ${ }^{* *} p<0.01$; Student's paired $t$ test.

Several classes of purinoceptors have been identified in taste buds, including P2X (ionotropic) and P2Y (metabotropic) purinoceptors. Over a decade ago, ionotropic ATP receptors (specifically P2X2 and P2X3), were identified in rat taste buds using immunostaining (Bo et al., 1999). These receptors were localized to the nerve fibers innervating taste buds, however, and the findings were interpreted as indicating ATP might be a neurotransmitter between taste buds and sensory afferent fibers. This immunolocalization was later replicated in mice and rats and additional findings further supported that interpretation (Cheung and Burnstock, 2002; Finger et al., 2005; Kataoka et al., 2006). However, a recent publication reported RT-PCR evidence for P2X2, P2X4, P2X7receptors in mouse taste bud cells and 


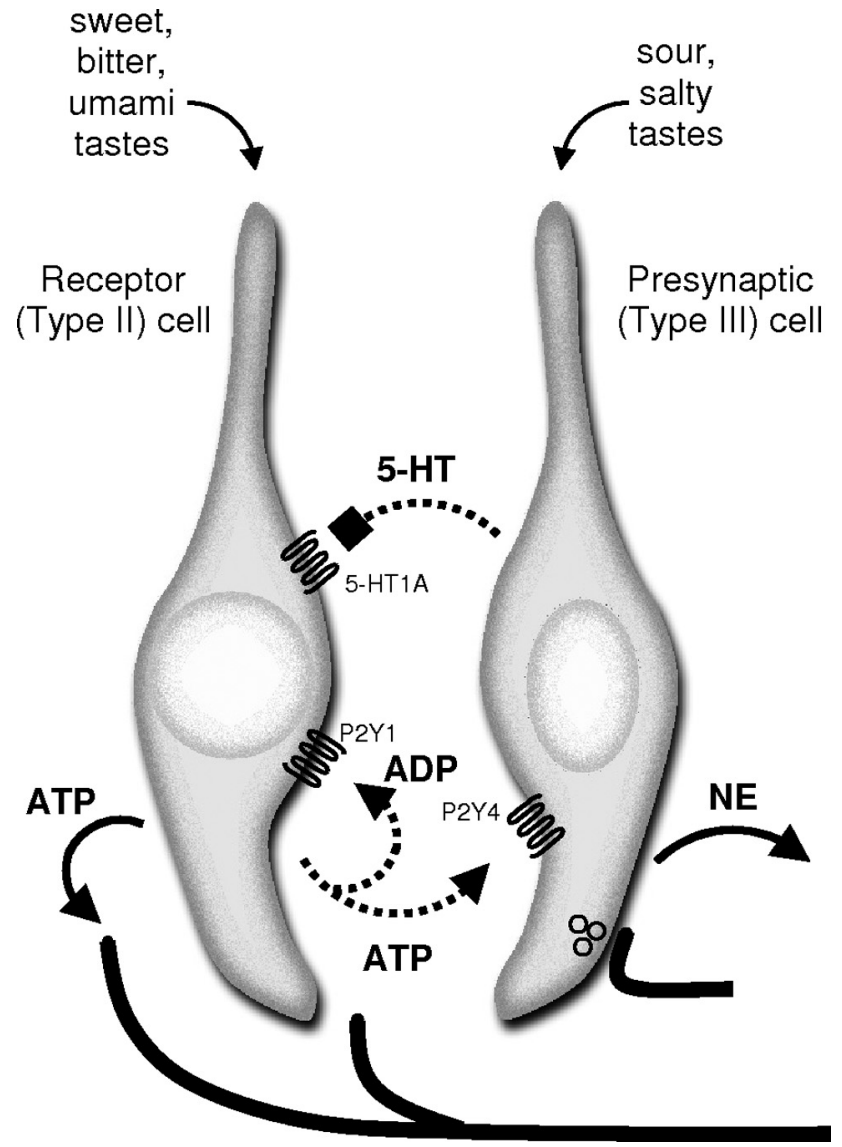

Figure 8. Schematic diagram of cell-to-cell communication in mouse taste buds. ATP and 5-HT mediate autocrine and paracrine interactions, respectively. Taste stimulation with bitter, sweet, or umami compounds excites receptor (type II) cells to secrete ATP as a transmitter (shown at bottom of receptor cell). ATP is believed to excite sensory afferent fibers (left) (Finger et al., 2005) and adjacent presynaptic (type III) taste cells (right) (Huang et al., 2007; Tomchik et al., 2007). ATP is catabolized by ecto-ATPase and the resultant ADP feeds back onto P2Y1 receptors on receptor cells to mediate autocrine excitation. Diffusion and further catabolism presumably limit purinergic positive feedback. Presynaptic taste cells release 5-HT and NE when stimulated by ATP or directly by acid taste stimulation (Huang et al., 2008). 5-HT released by presynaptic cells provides negative feedback onto receptor cells via $5-\mathrm{HT}_{1 \mathrm{~A}}$ receptors expressed by receptor cells. NE does not appear to participate in feedback mechanisms with receptor cells. Other postsynaptic targets for 5-HT and NE have not yet been identified with certainty. For clarity, type I cells have not been included in this figure.

showed immunostaining for one of these, P2X2, in some but not all presynaptic (type III) cells (Hayato et al., 2007). Moreover, these same investigators reported functional evidence of $\mathrm{P} 2 \mathrm{X}$ receptors in taste cells using $\mathrm{Ca}^{2+}$ imaging on pieces of lingual epithelium containing taste buds and exposed to bath application of $1 \mu \mathrm{M}$ ATP. Namely, bathing the tissue in $\mathrm{Ca}^{2+}$-free solution reduced the tonic portion of $\mathrm{Ca}^{2+}$ responses evoked by prolonged applications of ATP. Whereas other researchers interpreted a similar finding as evidence for store-operated $\mathrm{Ca}^{2+}$ influx consequent to intracellular $\mathrm{Ca}^{2+}$ release (Baryshnikov et al., 2003), Hayato et al. (2007) claimed their finding was functional evidence for P2X receptors. Neither Baryshnikov et al. (2003) nor Hayato et al. (2007) identified ATP-responding taste cells as receptor or presynaptic cells. Hayato et al. (2007) further suggested that higher concentrations of ATP activated P2X7 receptors in taste buds. In our experiments we did not see evidence for ionotropic receptors (P2X) contributing to ATP-evoked Ca signals in taste cells. This differs from Hayato et al. (2007). However, we used brief ATP applications (30 s) which minimized any prolonged tonic re- sponse, whether store-activated or $\mathrm{P} 2 \mathrm{X}$ receptor-activated. In brief, there is discrepancy in the literature regarding the presence of ionotropic ( $\mathrm{P} 2 \mathrm{X})$ receptors on taste bud cells. Our findings do not help resolve this controversy concerning $\mathrm{P} 2 \mathrm{X}$ receptors.

There is less controversy regarding the presence of P2Y purinoceptors on taste bud cells. Kolesnikov and his associates reported functional activation of $\mathrm{P} 2 \mathrm{Y}$ receptors in a subpopulation of mouse taste buds by applying ATP, UTP, and ADP (Kim et al., 2000; Baryshnikov et al., 2003). Baryshnikov et al. (2003) and later Bystrova et al. (2006) interpreted their findings as due to activating P2Y2, P2Y4, or both classes of receptors. These workers did not identify whether the responding cells were receptor or presynaptic taste cells, although from their records it is likely that both types were included. P2Y1 receptors in rat taste buds have been demonstrated by RT-PCR (Kataoka et al., 2004). Using $\mathrm{Ca}^{2+}$ imaging and RT-PCR, Bystrova et al. (2006) demonstrated that mouse circumvallate taste cells might express P2Y1, P2Y2, $\mathrm{P} 2 \mathrm{Y} 4$ and $\mathrm{P} 2 \mathrm{Y} 6$ receptors. According to our observations, presynaptic cells showed robust $\mathrm{Ca}^{2+}$ signals in response to ATP and UTP. This suggests presynaptic cells express P2Y2 and/or P2Y4 receptors. This conclusion is reinforced by the reduction (but not complete absence) of the incidence of ATP-evoked 5-HT release from taste buds of P2Y4 knock-out mice. Our findings extend those presented by Bystrova et al. (2006), specifically by identifying cell types expressing $\mathrm{P} 2 \mathrm{Y}$ receptors. In contrast with Bystrova et al. (2006), however, we show that P2Y1 receptors on receptor cells may also play an important role in mouse vallate taste buds.

It is noteworthy that because receptor cells express the P2Y1 subclass of purinoceptors, this makes them particularly sensitive to ADP. This sensitivity is consistent with the presence of a potent ecto-ATPase, NTPDase2, in taste buds (Bartel et al., 2006), that rapidly degrades ATP to ADP (Lazarowski et al., 2003; Matsuoka and Ohkubo, 2004). Thus, activity of ecto-ATPase during taste signaling generates the highly effective autocrine ligand, ADP.

Our findings also indicate a prominent inhibitory role for 5-HT in taste buds during taste reception and taste coding. Serotonin exerts negative feedback onto vallate taste receptor cells at concentrations as low as $10 \mathrm{nM}$. This negative feedback is manifested as an inhibition of ATP secretion from receptor cells and presumably therefore as an inhibition of signal output from the taste bud. Paroxetine, a 5-HT reuptake inhibitor, strengthened this inhibitory feedback in our experiments.

Although the inhibitory role of 5-HT remains to be tested carefully in behavioral assays of peripheral taste in experimental animals, observations on human taste thresholds are consistent with our findings. Namely, O'Driscoll et al. (2008) measured taste thresholds in healthy subjects before and after administering Seroxat or paroxetine, serotonin reuptake inhibitors designed to decrease peripheral 5-HT levels. They found that applying Seroxat topically onto the tongue, or paroxetine systemically, acutely reduced quinine (bitter) taste sensitivity in their subjects. This would be entirely consistent with our report here of an inhibitory role for 5-HT in taste bud function. Interestingly, the same group found that in contrast with these acute effects, chronic depression of 5-HT reuptake in healthy subjects increased taste sensitivity to sweet and bitter (Heath et al., 2006). There are other parallels in the literature regarding the effects of administering 5-HT, for example in amphibian taste buds. Ewald and Roper (1994) recorded from adjacent cells from taste buds in Necturus maculosus. Those researchers found that over the short term, repetitive stimulation of one taste cell hyperpolarized the adjacent cell, suggesting an inhibitory effect. This hyperpolarization was mimicked by bath-applied 5-HT. In other studies, 
Morimoto and Sato (1977) reported that in an intact frog tongue preparation, 5-HT acutely depressed taste sensitivity. Using a similar preparation, Esakov et al. (1983) found that at longer times after 5-HT (up to an hour) taste responses were enhanced. Esakov et al. (1983) interpreted these findings as indicating that serotonin had been taken up and subsequently released as an excitatory taste neurotransmitter, perhaps mirroring the chronic effects in humans reported by Heath et al. (2006). Collectively, all the above reports on short term effects of serotonin are resolved and clarified by the present findings that 5-HT exerts a rapid and potent paracrine inhibition of taste receptor activity.

In rat taste buds, Kaya et al. (2004) surmised that serotonin was a paracrine transmitter acting at $5-\mathrm{HT}_{1 \mathrm{~A}}$ receptors, although the identity of the cells expressing that receptor was not established. Those authors speculated that serotonin inhibited neighboring taste cells. [Vandenbeuch et al. (2008b) reported that BP554, a 5-HT HA $_{1}$ agonist, evoked responses in taste bud cells when applied at $10 \mu \mathrm{M}$. In our study, we did not observe $\mathrm{Ca}^{2+}$ transients in response to 5 -HT or its receptor agonists, but our experiments were conducted with much lower agonist concentrations (10 nM), which proved to be effective inhibitors.] Our data confirm and extend these previous findings of 5- $\mathrm{HT}_{1 \mathrm{~A}}$ receptor mechanisms and show where and how 5-HT acts as a paracrine inhibitory feedback signal.

Serotonin may also be a neurocrine transmitter, as speculated by Esakov et al. (1983). Presumably this would be at synapses that presynaptic cells make onto nerve fibers. Noradrenalin and serotonin are coreleased from presynaptic cells (Huang et al., 2008) and perhaps together these amines act at those synapses. There has been no resolution to this notion, however. Finger et al. (2005) reported that mice lacking one type of serotonin receptor, 5-HT3, showed no obvious taste behavior abnormalities. Detailed studies on these mice and on mutant strains lacking other types of 5-HT receptors are lacking. In short, to date there is no complete description for how or whether serotonin functions in taste buds as a neurocrine transmitter onto gustatory afferent axons.

Note added in proof. In the present report, we included the bitter tastant denatonium at a maximum concentration of $1 \mathrm{~mm}$ in our taste mix stimulus. A. Vandenbeuch and S. C. Kinnamon found that taste receptor cell responses elicited by the bitter tastant denatonium at concentrations of $5-10 \mathrm{~mm}$ were unaffected by serotonin (personal communication). We have replicated their results with 5-10 $\mathrm{mm}$ denatonium. It may be important to note that in a lingual slice preparation, Caicedo and Roper (2001) previously reported that $\sim 100 \mu \mathrm{M}$ denatonium evokes maximal responses in rat taste cells. Interestingly, Sawano et al. (2005) reported that $1 \mathrm{~mm}$ denatonium elicits both G-proteindependent and G-protein-independent responses in mouse taste cells. Collectively, these data suggest that high concentrations of denatonium (e.g., $\geq 5 \mathrm{~mm}$ ) might activate taste cells by mechanisms other than via GPCR taste receptors and resist inhibition by serotonin. The inhibitory serotonergic signal transduction pathway in taste cells and how this path interferes with taste GPRC pathways remain to be determined.

\section{References}

Bartel DL, Sullivan SL, Lavoie EG, Sévigny J, Finger TE (2006) Nucleoside triphosphate diphosphohydrolase-2 is the Ecto-ATPase of type I cells in taste buds. J Comp Neurol 497:1-12.

Baryshnikov SG, Rogachevskaja OA, Kolesnikov SS (2003) Calcium signaling mediated by P2Y receptors in mouse taste cells. J Neurophysiol 90:3283-3294.
Bo X, Alavi A, Xiang Z, Oglesby I, Ford A, Burnstock G (1999) Localization of ATP-gated P2X2 and P2X3 receptor immunoreactive nerves in rat taste buds. Neuroreport 10:1107-1111.

Bystrova MF, Yatzenko YE, Fedorov IV, Rogachevskaja OA, Kolesnikov SS (2006) P2Y isoforms operative in mouse taste cells. Cell Tissue Res 323:377-382.

Caicedo A, Roper SD (2001) Taste receptor cells that discriminate between bitter stimuli. Science 291:1557-1560.

Chattopadhyaya B, Di Cristo G, Higashiyama H, Knott GW, Kuhlman SJ, Welker E, Huang ZJ (2004) Experience and activity-dependent maturation of perisomatic GABAergic innervation in primary visual cortex during a postnatal critical period. J Neurosci 24:9598-9611.

Cheung KK, Burnstock G (2002) Localization of P2X3 receptors and coexpression with $\mathrm{P} 2 \mathrm{X} 2$ receptors during rat embryonic neurogenesis. J Comp Neurol 443:368-382.

Clapp TR, Medler KF, Damak S, Margolskee RF, Kinnamon SC (2006) Mouse taste cells with $\mathrm{G}$ protein-coupled taste receptors lack voltagegated calcium channels and SNAP-25. BMC Biol 4:7.

DeFazio RA, Dvoryanchikov G, Maruyama Y, Kim JW, Pereira E, Roper SD, Chaudhari N (2006) Separate populations of receptor cells and presynaptic cells in mouse taste buds. J Neurosci 26:3971-3980.

Dvoryanchikov G, Sinclair M, Perea-Martinez I, Wang T, Chaudhari N (2009) The inward rectifier channel, ROMK, is localized to the apical tips of glial-like cells in mouse taste buds. J Comp Neurol 516:(in press).

Esakov AI, Golubtsov KV, Solov'eva NA (1983) Significance of serotonin in the activity of the taste receptor apparatus of the frog Rana temporaria. $\mathrm{Zh}$ Evol Biokhim Fiziol 19:62-67.

Ewald DA, Roper SD (1994) Bidirectional synaptic transmission in Necturus taste buds. J Neurosci 14:3791-3804.

Finger TE, Danilova V, Barrows J, Bartel DL, Vigers AJ, Stone L, Hellekant G, Kinnamon SC (2005) ATP signaling is crucial for communication from taste buds to gustatory nerves. Science 310:1495-1499.

Geary C, Akinbi H, Korfhagen T, Fabre JE, Boucher R, Rice W (2005) Increased susceptibility of purinergic receptor-deficient mice to lung infection with Pseudomonas aeruginosa. Am J Physiol Lung Cell Mol Physiol 289:L890-L895.

Hayato R, Ohtubo Y, Yoshii K (2007) Functional expression of ionotropic purinergic receptors on mouse taste bud cells. J Physiol 584:473-488.

Heath TP, Melichar JK, Nutt DJ, Donaldson LF (2006) Human taste thresholds are modulated by serotonin and noradrenaline. J Neurosci 26: $12664-12671$.

Huang YA, Roper SD (2009) Serotonin inhibits ATP secretion in mouse taste buds. Chem Senses 34:A66-A67.

Huang YA, Maruyama Y, Roper SD (2008) Norepinephrine is co-released with serotonin in mouse taste buds. J Neurosci 28:13088-13093.

Huang YJ, Maruyama Y, Lu KS, Pereira E, Plonsky I, Baur JE, Wu D, Roper SD (2005) Mouse taste buds use serotonin as a neurotransmitter. J Neurosci 25:843-847.

Huang YJ, Maruyama Y, Dvoryanchikov G, Pereira E, Chaudhari N, Roper SD (2007) The role of pannexin 1 hemichannels in ATP release and cell-cell communication in mouse taste buds. Proc Natl Acad Sci U S A 104:6436-6441.

Kataoka S, Toyono T, Seta Y, Ogura T, Toyoshima K (2004) Expression of P2Y1 receptors in rat taste buds. Histochem Cell Biol 121:419-426.

Kataoka S, Toyono T, Seta Y, Toyoshima K (2006) Expression of ATP-gated $\mathrm{P} 2 \mathrm{X} 3$ receptors in rat gustatory papillae and taste buds. Arch Histol Cytol 69:281-288.

Kaya N, Shen T, Lu SG, Zhao FL, Herness S (2004) A paracrine signaling role for serotonin in rat taste buds: expression and localization of serotonin receptor subtypes. Am J Physiol Regul Integr Comp Physiol 286:R649-R658.

Kilpatrick GJ, Butler A, Burridge J, Oxford AW (1990) 1-(m-Chlorophenyl)biguanide, a potent high affinity 5-HT3 receptor agonist. Eur J Pharmacol 182:193-197.

Kim JW, Roberts C, Maruyama Y, Berg S, Roper S, Chaudhari N (2006) Faithful expression of GFP from the PLCbeta2 promoter in a functional class of taste receptor cells. Chem Senses 31:213-219.

Kim YV, Bobkov YV, Kolesnikov SS (2000) ATP mobilizes cytosolic calcium and modulates ionic currents in mouse taste receptor cells. Neurosci Lett 290:165-168.

Lawton DM, Furness DN, Lindemann B, Hackney CM (2000) Localization 
of the glutamate-aspartate transporter, GLAST, in rat taste buds. Eur J Neurosci 12:3163-3171.

Lazarowski ER, Boucher RC, Harden TK (2003) Mechanisms of release of nucleotides and integration of their action as P2X- and P2Y-receptor activating molecules. Mol Pharmacol 64:785-795.

Lu SG, Zhao FL, Herness S (2003) Physiological phenotyping of cholecystokinin-responsive rat taste receptor cells. Neurosci Lett 351:157-160.

Matsuoka I, Ohkubo S (2004) ATP- and adenosine-mediated signaling in the central nervous system: adenosine receptor activation by ATP through rapid and localized generation of adenosine by ectonucleotidases. J Pharmacol Sci 94:95-99.

Morán A, Ortiz de Urbina AV, Martín ML, García M, Rodriguez-Barbero A, Dorado F, San Román L (2008) Characterization of contractile 5-hydroxytryptamine receptor subtypes in the in situ autoperfused kidney in the anaesthetized rat. Eur J Pharmacol 592:133-137.

Morimoto K, Sato M (1977) Is serotonin a chemical transmitter in the frog taste organ? Life Sci 21:1685-1695.

Mutafova-Yambolieva VN, Hwang SJ, Hao X, Chen H, Zhu MX, Wood JD, Ward SM, Sanders KM (2007) Beta-nicotinamide adenine dinucleotide is an inhibitory neurotransmitter in visceral smooth muscle. Proc Natl Acad Sci U S A 104:16359-16364.

Nagahama S, Kurihara K (1985) Norepinephrine as a possible transmitter involved in synaptic transmission in frog taste organs and Ca dependence of its release. J Gen Physiol 85:431-442.

Nagai T, Delay RJ, Welton J, Roper SD (1998) Uptake and release of neurotransmitter candidates, $\left[{ }^{3} \mathrm{H}\right]$ serotonin, $\left[{ }^{3} \mathrm{H}\right]$ glutamate, and $\left[{ }^{3} \mathrm{H}\right]$ gammaaminobutyric acid, in taste buds of the mudpuppy, Necturus maculosus. J Comp Neurol 392:199-208.
O'Driscoll S, McRobie E, Ayres C, Mileusnic N, Heath TP, Melichar JK, Donaldson LF (2008) Serotonin-specific reuptake inhibitors (SSRI) blunt bitter taste acutely (minutes), but enhance it chronically (hours) in normal healthy humans. Proc Physiol Soc 11:PC102.

Ogura T (2002) Acetylcholine increases intracellular Ca2 + in taste cells via activation of muscarinic receptors. J Neurophysiol 87:2643-2649.

Romanov RA, Rogachevskaja OA, Bystrova MF, Jiang P, Margolskee RF, Kolesnikov SS (2007) Afferent neurotransmission mediated by hemichannels in mammalian taste cells. EMBO J 26:657-667.

Sawano S, Seto E, Mori T, Hayashi Y (2005) G-protein-dependent and -independent pathways in denatonium signal transduction. Biosci Biotechnol Biochem 69:1643-1651.

Tomchik SM, Berg S, Kim JW, Chaudhari N, Roper SD (2007) Breadth of tuning and taste coding in mammalian taste buds. J Neurosci 27: $10840-10848$.

Vandenbeuch A, Clapp TR, Kinnamon SC (2008a) Amiloride-sensitive channels in type I fungiform taste cells in mouse. BMC Neurosci 9:1.

Vandenbeuch A, Burks CA, Kinnamon SC (2008b) Response to serotonin agonist in mouse type II taste cells. Chem Senses 33:S38.

Yang R, Crowley HH, Rock ME, Kinnamon JC (2000) Taste cells with synapses in rat circumvallate papillae display SNAP-25-like immunoreactivity. J Comp Neurol 424:205-215.

Yee CL, Yang R, Böttger B, Finger TE, Kinnamon JC (2001) “Type III” cells of rat taste buds: immunohistochemical and ultrastructural studies of neuron-specific enolase, protein gene product 9.5, and serotonin. J Comp Neurol 440:97-108.

Zhao FL, Shen T, Kaya N, Lu SG, Cao Y, Herness S (2005) Expression, physiological action, and coexpression patterns of neuropeptide $\mathrm{Y}$ in rat taste-bud cells. Proc Natl Acad Sci U S A 102:11100-11105. 